\title{
Water under the bridge: a rare case of scrotal cystocele
}

\author{
Kathleen Dass, ${ }^{1}$ Reem Daloul, ${ }^{2}$ Priya Gupta ${ }^{2}$
}

${ }^{1}$ Department of Internal Medicine, William Beaumont Hospital, Bloomfield Hills, Michigan, USA

${ }^{2}$ William Beaumont Hospital, Royal Oak, Michigan, USA

\section{Correspondence to}

Dr Kathleen Dass,

kathleen.j.dass@gmail.com

\section{DESCRIPTION}

Large sliding inguinal hernias involving the urinary bladder are rare. If left untreated, the effect can be devastating, leading to bladder infarction, perforation or obstruction. The urinary bladder is involved in $1-4 \%$ of all inguinal hernias. ${ }^{1}$ Review of the

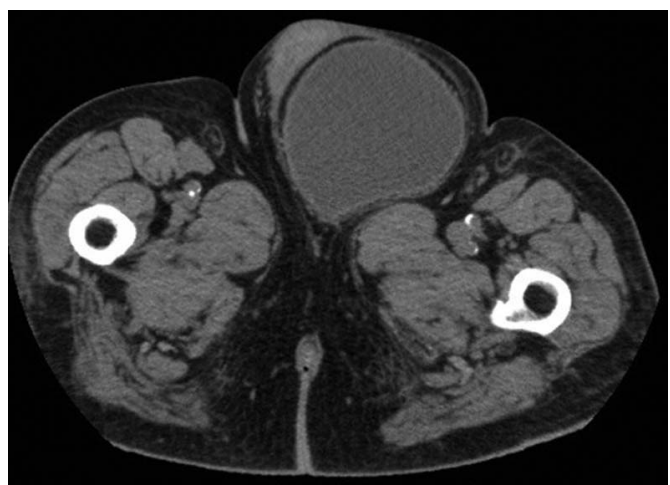

Figure 1 Axial view showing non-contrast $\mathrm{CT}$ of the abdomen/pelvis highlighting the bladder inside the scrotum.

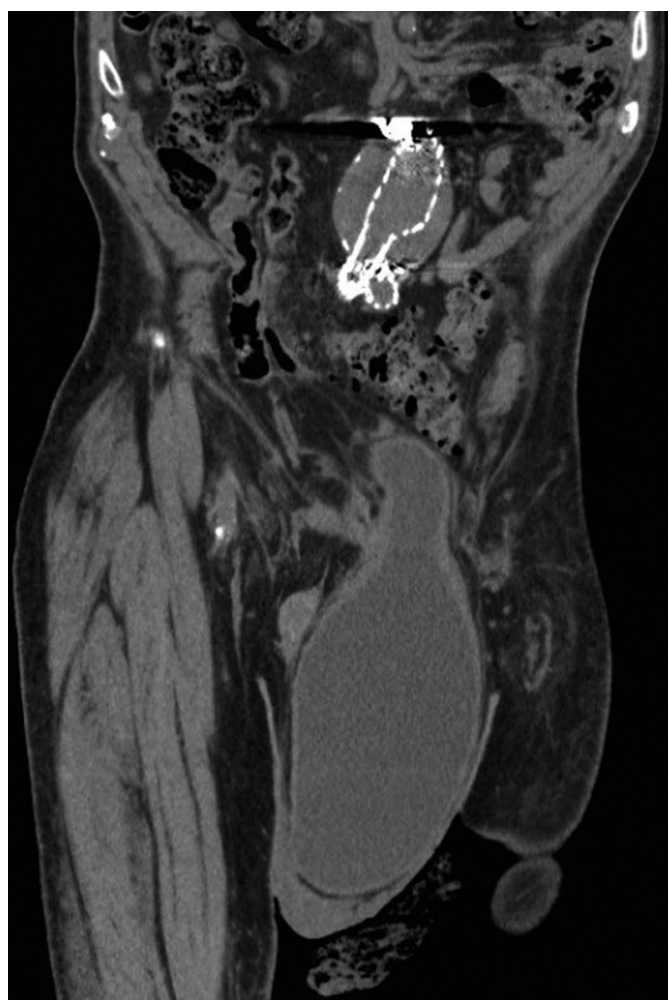

Figure 2 Sagittal view showing non-contrast CT of the abdomen/pelvis showcasing the bladder herniating into the scrotum. literature reveals that large scrotal cystoceles are very rare, occurring in fewer than $1 \%$ of cases and are diagnosed preoperatively in less than $7 \%$ of cases. ${ }^{2}$ An ultrasound and CT of the scrotum and pelvis can aid in the evaluation of a scrotal cystocele (figures 1 and 2). ${ }^{3}$ When identified, the patient should have prompt surgical intervention to prevent complications that include haematuria, fistulas, sepsis, bladder infarction and hydronephrosis. ${ }^{2}{ }^{3}$ Herniorraphies are performed through inguinal incisions. However, there are case reports of success with laparoscopic and robotic techniques with scrotal cystoceles. $^{2}$

\section{Learning points}

- Large sliding inguinal hernias involving the urinary bladder are rare with two-phase micturition as the only discomfort frequently cited.

- CT findings, such as in the image provided, include (but are not limited to) bladder wall indentation, asymmetry of the herniated structures in abnormal locations and the ureter located beyond the pelvic bones.

- When identified, the patient should have prompt surgical intervention to prevent complications that include haematuria, fistulas, sepsis, bladder infarction and hydronephrosis.

Competing interests None.

Patient consent Obtained.

Provenance and peer review Not commissioned; externally peer reviewed.

\section{REFERENCES}

1 Bisharat $M, O^{\prime}$ Donnell $M$, et al. Complications of inguinoscrotal bladder hernias: a case series. Hernia 2009;13:81-4.

2 Lee J, Oh S, et al. Laparoscopic repair of large bladder herniation presenting as an inguinal hernia. Korean J Urol 2013;54:139-42.

3 Bjurlin M, DeLaurentis D. Clinical and radiographic findings of a sliding inguinoscrotal hernia containing the urinary bladder. Hernia 2010;14:635-8.
To cite: Dass K, Daloul R Gupta P. BMJ Case Rep Published online: [please include Day Month Year doi:10.1136/bcr-2013 200239 
Copyright 2013 BMJ Publishing Group. All rights reserved. For permission to reuse any of this content visit http://group.bmj.com/group/rights-licensing/permissions.

BMJ Case Report Fellows may re-use this article for personal use and teaching without any further permission.

Become a Fellow of BMJ Case Reports today and you can:

- Submit as many cases as you like

- Enjoy fast sympathetic peer review and rapid publication of accepted articles

- Access all the published articles

- Re-use any of the published material for personal use and teaching without further permission

For information on Institutional Fellowships contact consortiasales@bmjgroup.com

Visit casereports.bmj.com for more articles like this and to become a Fellow 